\title{
Enterochromaffin-like (ECL) Cells Hyperplasia in Fundic Gland Polyp and Its Association with the Usage of Proton Pump Inhibitors
}

\author{
Ening Krisnuhoni*, Fili Sufangga**, Diah Rini Handjari*, Nur Rahadiani*, \\ Marini Stephanie* \\ *Division of Gastrointestinal and Hepatobiliary Pathology, Department of Anatomical Pathology \\ Faculty of Medicine, Universitas Indonesia/Dr. Cipto Mangunkusumo General National Hospital \\ Jakarta \\ ${ }^{* *}$ Department of Anatomical Pathology Residency Program, Faculty of Medicine \\ Universitas Indonesia/Dr. Cipto Mangunkusumo General National Hospital, Jakarta
}

\begin{abstract}
Corresponding author:
Ening Krisnuhoni. Division of Gastrointestinal and Hepatobiliary Pathology, Department of Anatomical Pathology, Dr. Cipto Mangunkusumo General National Hospital. Jl. Diponegoro No.71 Jakarta Indonesia. Phone:+62-21-31930487; facsimile:+62-21-31934465. E-mail: ening.krisnuhoni@yahoo.com
\end{abstract}

\section{ABSTRACT}

Background: As one of the most prescribed drugs, long-term use of proton pump inhibitors (PPI) had been known to cause gastrointestinal structural changes. One of which is hyperplasia and hypertrophy of enterochromaffin-like (ECL) cells, characterized as dilation of oxyntic glands and parietal cell protrusions. ECL cell hyperplasia is one of the risk factors associated with several gastric neoplasms. This study attempted to clarify the link between PPI use and ECL cell hyperplasia among patients with long and short-term PPI use.

Method: A cross-sectional study conducted among patients with fundic gastric polyps (FGP) underwent pathologic evaluation in Cipto Mangunkusumo Hospital in 2016-2017 by evaluating archive slides and medical records. Clinical data included age, sex, and history of PPI were recorded. Tissue slides of the polyp samples are reexamined double-blindly. ECL cell hyperplasia is defined as 4 or more cells stained with chromogranin $A$ in one gland, and at least 2 eligible glands, both in polypomatous and non-polypomatous lesions. Bivariate data analyses were done using Fisher's exact test with p-values $<0.05$ are considered significant.

Results: We discover 40 cases, categorized into 25 cases with long-term PPI use and 15 cases with short-term PPI use. Twelve cases (30\%) present with ECL cell hyperplasia: 9 and 3 cases of long-term and short-term PPI use, respectively. Among cases without ECL cell hyperplasia; 16 and 12 had a history of long and short-term PPI use, respectively. The result was statistically insignificant $(p=0.241)$.

Conclusion: In the population diagnosed with FGP in 2016-2017, there is no statistically significant difference between ECL cell hyperplasia in long-term and short-term PPI users.

Keywords: enterochromaffin-like cell, fundic gastric polyp, hyperplasia, proton-pump inhibitor

\section{ABSTRAK}

Latar belakang: Sebagai salah satu obat yang paling banyak diresepkan, penggunaan penghambat pompa proton (PPI) jangka panjang diketahui menyebabkan perubahan struktural saluran cerna. Salah satunya adalah hiperplasia dan hipertrofi sel enterochromaffin-like (ECL), yang ditandai dengan pelebaran kelenjar oksintik 
dan penonjolan sel parietal. Hiperplasia sel ECL adalah salah satu faktor risiko terjadinya berbagai keganasan lambung. Penelitian ini mencoba untuk mengetahui hubungan antara penggunaan PPI dengan hiperplasia sel ECL pada pasien dengan penggunaan PPI jangka panjang dan jangka pendek.

Metode: Studi potong lintang dilakukan pada pasien dengan polip fundus lambung (FGP) yang menjalani evaluasi patologi di RS Cipto Mangunkusumo tahun 2016-2017 dengan melakukan telaah pada sediaan patologi dan rekam medis patient. Data klinis berupa usia, jenis kelamin, dan riwayat penggunaan PPI juga dicatat. Slide patologi diperiksa ulang dengan metode tersamar ganda. Hiperplasia sel ECL didefinisikan sebagai ditemukannya 4 atau lebih sel yang diwarnai dengan kromogranin A dalam satu kelenjar, dengan setidaknya terdapat 2 kelenjar yang memenuhi syarat, baik pada lesi polipomatous maupun nonpolipomatous. Analisis data bivariat dilakukan dengan menggunakan Fisher's Exact Test dengan p-value < 0,05 dianggap signifikan.

Hasil: Studi ini menemukan 40 kasus yang kemudian dikategorikan menjadi 25 kasus dengan penggunaan PPI jangka panjang dan 15 kasus dengan penggunaan PPI jangka pendek. Dua belas kasus (30\%) ditemukan hiperplasia sel ECL: 9 dan 3 kasus pada penggunaan PPI jangka panjang dan jangka pendek, secara berturutturut. Di antara kasus tanpa hiperplasia sel ECL: 16 dan 12 memiliki riwayat penggunaan PPI jangka pendek dan panjang, secara berturut-turut. Hasil ini tidak signifikan secara statistik ( $p=0,241)$.

Simpulan: Pada populasi yang terdiagnosis FGP tahun 2016-2017, tidak terdapat perbedaan yang bermakna secara statistik antara hiperplasia sel ECL pada pengguna PPI jangka panjang dan jangka pendek.

Kata kunci: hiperplasia, penghambat pompa proton, polip fundus lambung fundus, sel enterochromaafin-like

\section{INTRODUCTION}

Introduced in 1988, proton pump inhibitors (PPIs) are one of the most prescribed type of drugs in the world. ${ }^{1}$ The mechanism of action of PPIs is supression of gastric acid production by stopping the $\mathrm{H}^{+} / \mathrm{K}^{+}$-ATPase pumps of the gastric parietal cells, and so it is currently used in the medication of diseases related to overproduction of gastric acid such as gastrooesophageal reflux disease and peptic ulcer. ${ }^{2}$ However, long-term use of PPI can cause structural changes of the stomach mucosa. One of these changes are hyperplasia and hypertrophy of enterochromaffinlike (ECL) cells, arising as a result of hypergastrinemia, with characteristic dilation of oxyntic glands and parietal cell protrusions, causing a serrated-glandular appearance. $^{3}$

ECL cell hyperplasia is one of the risk factors associated with several neoplasms such as fundal gland polyps (FGPs) and gastric carcinoid tumors. A study by Jalving et al suggested a risk increase of as much as four times for FGP formation for long-term PPI users. ${ }^{4}$ Fiocca et al. reported ECL hyperplasia in patients using esomeprazole for 5 years, although no dysplastic or neoplastic lesions were found. ${ }^{5}$ Jianu et al reported 2 patients with 12-13 years of PPI use and well-differentiated gastric neuroendocrine neoplasms and ECL cell hyperplasia. The termination of PPI use causes visible regression of tumor mass and hyperplasia. ${ }^{6}$ Tatsuguchi et al shown ECL hyperplasia in 20 patients with long-term PPI use, but with no dysplastic lesions.?

Therefore, this study attempted to clarify the significance of the link between PPI use and ECL cell hyperplasia, by comparing the extent of ECL cell hyperplasia in patients with long-term vs. short-term PPI use.

\section{METHOD}

The study is a cross-sectional study with retrospective data conducted at the Anatomic Pathology Department, Faculty of Medicine, Universitas Indonesia - Cipto Mangunkusumo National Central General Hospital (RSCM), Jakarta, which examined patients with fundic gastric polyps in RSCM in the years 20162017, especially those diagnosed in the Anatomical Pathology Department. All patients diagnosed with fundic gastric polyps in the center in the years 20162017 are included in this study. Samples excluded are those with microscopically proven moderate to severe atrophy, and with clinical data showing that the patients did not use proton pump inhibitors during treatment, or used other anti-gastric secretion drugs.

From the available population, samples are taken according to the inclusion criteria by total population sampling. Concordance between clinical and pathological archive data finally confirmed a total of forty samples taken to be studied further. Several 
operational definitions are formulated for this study to simplify decision-making, as follows: (1) Fundic gland polyps are polyps with characteristic proliferation/ hyperplasia of oxyntic glands reaching nearly the mucosal surface, causing foveolar shortening and atrophy accompanied with cystic dilatation of glands. Glands are structures covered in parietal cells, chief cells, and mucosal neck cells; (2) Long-term PPI use is defined as PPI use (as documented by prescription) recorded in the medical records or found via telephone interview to be accepted by the patient, either intermittently or without pause, for 12 months or more prior to EGD; (3) Short-term PPI use is defined as PPI use (as documented by prescription) recorded in the medical records or found via telephon interview to be accepted by the patient, either intermittently or without pause, for less than 12 months prior to EGD; (4) The normal control specimens used for this study are specimens of neuroendocrine tumors which are proven to be positively stained for chromogranin A with a granular pattern in the cytoplasm; (5) Enterochromaffin-like cell hyperplasia is defined by the presence of four or more cells in the oxyntic glands which positively stained for chromogranin A, in at least 2 glandular structures per $\mathrm{mm}$ of tissue (according to the modified criteria presented by Solcia et al). ${ }^{8,9}$

Collection of archive slides and medical records of the determined cases were done, including clinical and histopathological data. Clinical data included age, sex, and history of PPI use. Prior diagnoses are also recorded. Tissue slides of the polyp samples are thenreexamined by two of the authors (EK and NR) double-blindedly.

Paraffin blocks of the fundal tissue sample are cut into 3-4 $\mu \mathrm{m}$ portions and put onto object glasses coated by poly-l-lysine. The preparations are then heated on the slide warmer at a temperature of $56{ }^{\circ} \mathrm{C}$ for 60 minutes. They are then deparaffinized 3 times with xylol for 5 minutes each, and then rehydrated with multiple concentrations of alcohol (absoloute, $96 \%$, and $70 \%$ ) for 5 minutes each. After washing with running water for 2 minutes, pretreatment with antigen retrieval procedure was done in a decloaking chamber using Tris-EDTA at a $\mathrm{pH}$ of 9, temperature of $96{ }^{\circ} \mathrm{C}$, for 10 minutes, and then cooled in room temperature for 45 minutes. The preparations were washed twice for 5 minutes each with phosphate buffer saline (PBS) in a $\mathrm{pH}$ of 7.4. They were then dried and circled with PAP pen to prevent fluid flowing to the sides of the slide. The tissue was incubated with protein block (Novolink Polymer ${ }^{\circledR}$, Novocastra) for 10 minutes, washed with PBS for 2 minutes, incubated with chromogranin A primary antibody LK2H10 (monoclonal antibody) with a dilution of 1:500 for 1 hour, washed again with PBS ( $\mathrm{pH}$ 7.4) for 3 minutes, and incubated with post-primary (Novolink Polymer ${ }^{\circledR}$, Novocastra) for 30 minutes, and again washed with PBS (pH 7.4) for 3 minutes. A secondary antibody (Novolink Polymer ${ }^{\circledR}$, Novocastra) is applied for 30 minutes and then washed with PBS ( $\mathrm{pH} \mathrm{7.4)} \mathrm{for} 3$ minutes. At the end, a coating of diaminobenzidine tetrahydrochloride (Novolink Polymer ${ }^{\circledR}$, Novocastra) was applied for 1 minute and then washed with running water for 2 minutes. Counterstaining was done with Mayer's hematoxylin and lithium carbonate, before dehydration with increasingly higher concentrations of alcohol (70\%, 96\%, absoloute), clearing with xylol I, II, and III, and completion of the preparation through closing with a cover glass. Both positive and negative controls were also put through the staining proccess. Positive controls are neuroendocrine tumors positively stained for chromogranin and synaptophysin, while negative controls are samples not incubated with primary antibodies.

The expression of chromogranin A is interpreted to be positive if the cell is stained brown with chromogranin A in the cytoplasm in a granular pattern. ECL cell hyperplasia is defined based on the research of Solcia et al. ${ }^{9}$ with modification, which posits the criteria of 4 or more cells stained with chromogranin A in one gland, and at least 2 eligible glands per mm of oxyntic mucosa both in polypomatous and non-polypomatous lesions. The observation on all slides was done by EK and NR in a double-blinded manner

Data analysis was done with the software SPSS version 23.0. Categoric data are calculated and displayed as proportions and percentages. Bivariate data analyses were done using Fisher's exact test, because the hypothesis of this study being an analytic correlative categoric hypothesis among two unrelated groups. p-values under 0.05 are interpreted as significant in correlating between variables.

\section{RESULTS}

Using total population sampling retrospectively in records of two years of fundic gastric polyp cases (2016-2017), we discover 40 cases, categorized into 25 cases with long-term PPI use and 15 cases with short-term PPI use. 
The mean age for the research subjects is $61.2 \pm$ 11.7 years old. The youngest subject is 31 years old, and the oldest is 90 years old. The majority of study subjects are females $(n=32 ; 80 \%)$

Assessment of chromogranin A immunohistochemistry was done by counting the number of posi- tively stained ECL cells. Either weakly, moderately, and strongly positive stains were all counted as positive. Positive control of chromogranin A staining was done using samples of neuroendocrine tumors with a minimum of two positive neuroendocrine tumor markers.

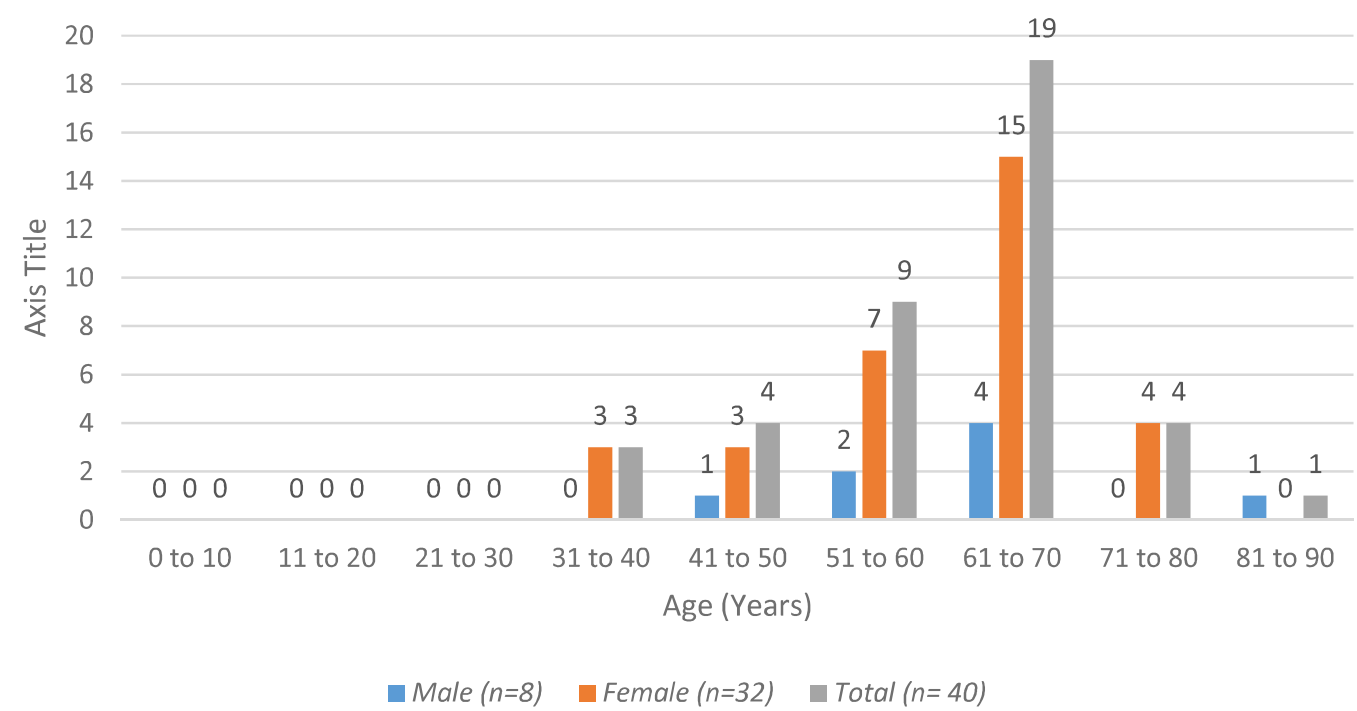

Figure 1. Characteristics of research subjects
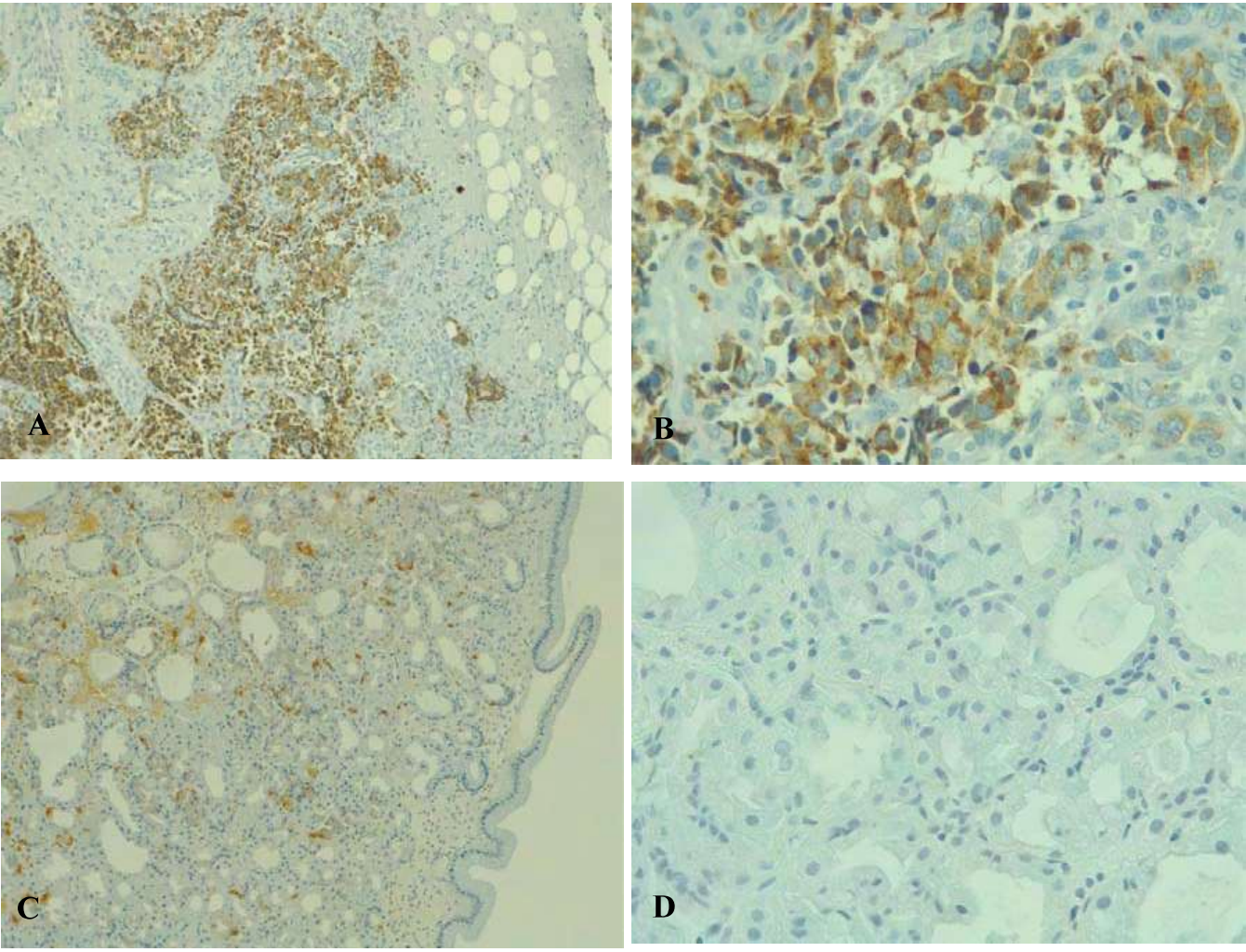

Figure 1. Positive expression of chromogranin $A$ in the cytoplasm of neuroendocrine carcinoma, in 100X magnification (A), and $400 X$ magnification (B). Negative expression of chromogranin $A$ on unstained negative control, in 100X magnification (C), and 400X magnification (D). 

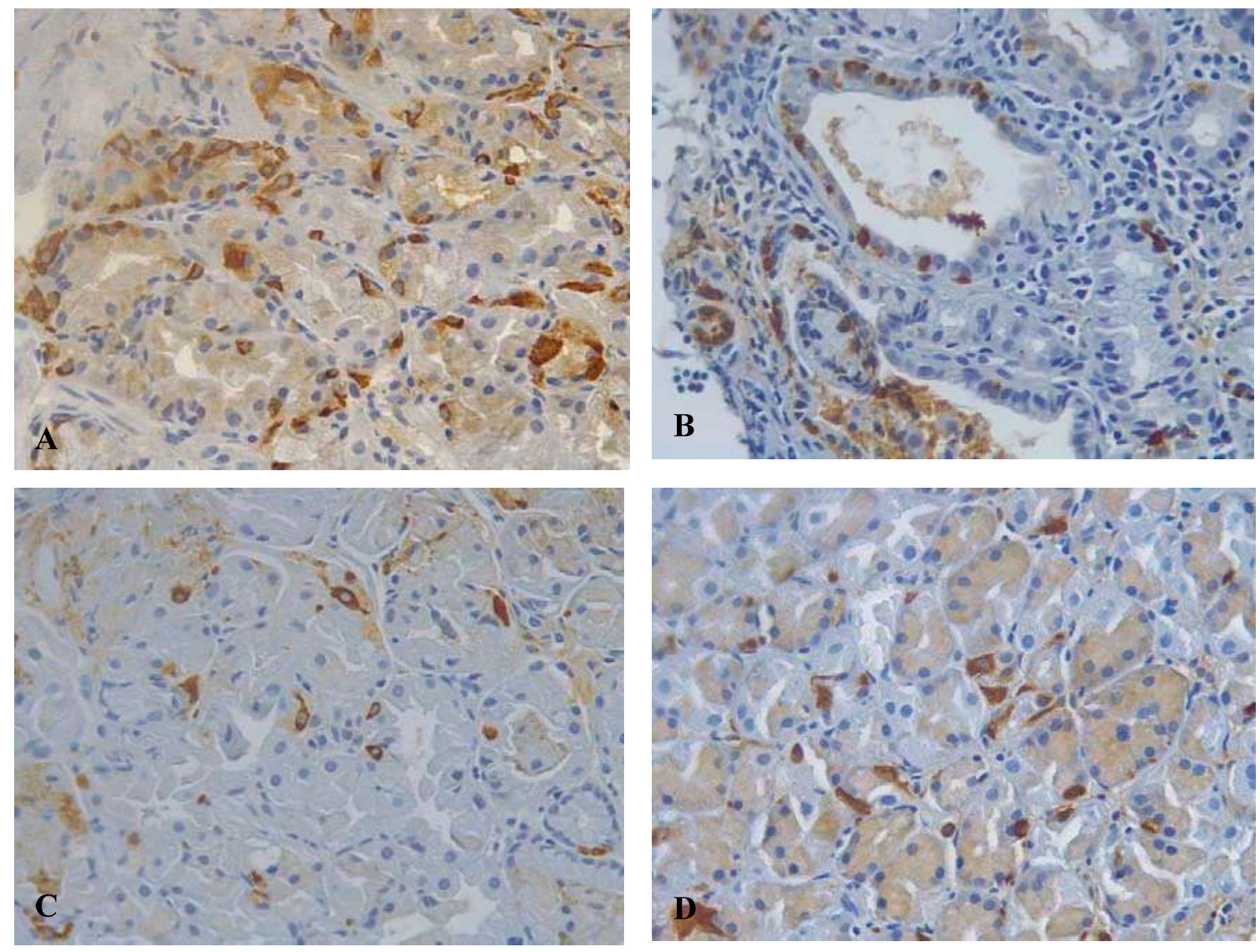

Figure 2. (A) Chromogranin A expression in ECL cell hyperplasia in a case of FGP with long-term PPI use (case number 26), 400X magnification. (B) Chromogranin A expression in ECL cell hyperplasia in a case of FGP with short-term PPI use (case number 19), 400X magnification. (C) Normal amount of ECL cells in a case of FGP with long-term PPI use (case number 35), 400X magnification. (D) Normal amount of ECL cells in a case of FGP with short-term PPI use (case number 18), 400X magnification

ECL cells are spread inhomogeneously in the lower third of the glandular structures, and the lamina propria, generally close in proximity to chief cells. ${ }^{10}$ In this study, hyperplasia of ECL cells is assessed using the criteria explained in Solcia et al with modification. ${ }^{9}$ The criteria defines hyperplasia as having four or more cells positively staining for chromogranin A for at least two glands per mm of tissue.

Based on the criteria, 12 cases (30\%) present with ECL cell hyperplasia. Nine cases have a history of long-term PPI use, and 3 cases with short-term PPI use. (Figure 2, A and B). Twenty eight cases (70\%) were found without ECL cell hyperplasia; among which 16 present with a history of long-term PPI use and 12 with short-term PPI use. (Figure 2, C and D).

There are several patterns of hyperplasia discovered in the 12 cases of ECL cell hyperplasia found, which are simple, linear, and micronodular hyperplasia. One case present with micronodular hyperplasia, 2 cases present with both simple and micronodular hyperplasia, 5 cases with simple hyperplasia, and 2 cases with simple and linear hyperplasia.
A Fisher's exact test was done to correlate between chromogranin A expression in FGP cases with the duration of PPI use. The result was found to be not statistically significant $(\mathrm{p}>0.05)$, as shown on Table 2 .

Table2. Correlation of chromogranin A expression to duration of proton pump inhibitor (PPI) use

\begin{tabular}{|c|c|c|c|}
\hline \multirow[b]{2}{*}{$\begin{array}{c}\text { Duration of } \\
\text { PPI }\end{array}$} & \multicolumn{2}{|c|}{ Chromogranin A expression } & \multirow[b]{2}{*}{$\mathbf{p}^{*}$} \\
\hline & $\begin{array}{c}\text { ECL cell } \\
\text { hyperplasia (\%) }\end{array}$ & $\begin{array}{c}\text { No hyperplasia } \\
(\%)\end{array}$ & \\
\hline Long-term & $9(36)$ & $16(64)$ & 0.241 \\
\hline Short-term & $3(20)$ & $12(80)$ & \\
\hline
\end{tabular}

*A Fisher's exact test is statistically significant when $p<0.05$

\section{DISCUSSION}

Fundic gland polyps are growths of the glandular layer of the gastric epithelium containing parietal cells and neck gland cells. ${ }^{4,11}$ The aforementioned study by Jalving et al. proposes an etiology related to parietal gland hyperplasia and cell protrusions related to ECL cell hyperplasia, while Vos et al relates it to increased gastrin production leading to trophism of oxyntic mucosa and signalling of the Wnt pathway. ${ }^{4}$ FGPs can be sporadic or associated with syndromes such as 
familial adenomatous polyposis (FAP). Sporadic FGPs are more prevalent in patients with no Helicobacter pylori infection and extensive PPI use. While they are generally considered as nonneoplastic (mostly hamartomatous or hyperplastic, due to being retention cysts due to impaired glandular secretions), discovery of mutations of genes in the Wnt pathway, such as $A P C$ and $C T N N B 1$, suggested that there is a neoplastic aspect to this disease entity. $60-90 \%$ of sporadic FGPs without dysplasia may present with somatic CTNNB1 mutation, while dysplastic sporadic FGPs may present with somatic $A P C$ mutation without $C T N N B 1$ mutation. In contrast, syndromic FGPs appear with second-hit $A P C$ inactivation preceding dysplasia. Most sporadic FGPs extremely rarely progress into dysplasia, is indolent, and regress with cessation of PPI. ${ }^{11}$ Individual factors, such as duration of PPI exposure, chronic autoimmune/H. pylori gastritis, a phenotype of PPI-slow metabolizer (i.e., mutations of the CYP genes responsible for metabolism of PPIs), as well as other mutations such as MEN-1, somatostatin response mutations, and absence mutations of genes producing the $\mathrm{H}^{+} / \mathrm{K}^{+}$-ATPase may affect ECL cell hyperplasia and dysplasia, and thus are risk factors for ECL cell neoplasia. ${ }^{12}$

Syndromic FGPs, often suspected with younger patients presenting with FGPs, usually as multiple/ dysplastic lesions, have a more grave prognosis due to association with other lesions throughout the alimentary tract (especially colorectal polyps and cancer). Low-grade dysplasia is also often known in syndromic FGPs, and result in higher risk of gastric cancer in Japanese and South Korean populations due to higher prevalence of Helicobacter pylori infection, atrophic gastritis, and intestinal metaplasia. Several types of FAP variants with higher risk of cancer are also now known in western populations. ${ }^{11}$

This study is the first to correlate between PPI use and ECL hyperplasia in Indonesian cases of FGP. The male-to-female ratio of the case group is 1:4. This is similar to data presented by Gao et al for all gastric polyps, in which more females suffered from gastric polyps than males. ${ }^{13}$ For all cases, immunohistochemistry staining for chromogranin A was done to facilitate recognition of ECL cells, which are harder to find with standard hematoxyllin-eosin staining. The classification of long-term (over 1 year) and short-term (under 1 year) PPI use is based on a study which suggested that 1 year of PPI use is a risk factor for FGP development. ${ }^{8}$
The identification of ECL cells as hyperplastic in this study, as in several others, is based off of research done by Solcia et al classifying ECL cell hyperplasias into several types: simple/diffuse (4 ECL cells in an oxyntic gland), linear (five ECL cells in a gland formed in a chain shape), micronodular (groups of five or more ECL cells, not larger than the gland diameter, located in the gland or the lamina propria), and adenomatoid (groups of five or more ECL cells, clumped closely together, located in the basal membrane). ${ }^{9}$ This criteria is modified with an additional criteria that over 2 glands per mm of tissue has to be positively stained with the above criteria, This is to add more specificity to the staining result. Expectedly, several staining results show that chromogranin A staining is proven positive not only in cells suspected to be ECL cells, but also cells suspected to be other neuroendocrine cells, parietal cells, and chief cells via HE staining.

Hage et al studied two groups of patients with long-term omeprazole use due to chronic illnesses (a mean duration of 7.5 years), and found that $41 \%$ of 25 patients with systemic sclerosis suffered from diffuse ECL hyperplasia, and patients with ZollingerEllison syndrome developed linear and micronodular hyperplasia. ${ }^{14}$ Fiocca et al compared patients with GERD and a therapy of anti-reflux laparoscopy vs. 5 years of esomeprazole use. ${ }^{5}$ It was discovered that patients with 5 years of esomeprazole use show signs of ECL hyperplasia vs. decreased ECL cell count in the anti-reflux laparoscopy wing. A study by Camilo et al did not show significant differences between ECL cell, G cell, and D cell counts in PPI users vs. non-PPI users. ${ }^{15} \mathrm{~A}$ compendium of cases of gastric neuroendocrine tumors (ECL cell dysplasia originating from ECL cell hyperplasia) in patients with longterm PPI use has been reported by McCarthy, with an appendix of brief case outlines referencing the papers describing these cases. ${ }^{12}$ Tatsuguchi et al in his surveillance study of 12 patients with long-term PPI use, reported ECL cell hyperplasia in all patients, but not more advanced dysplastic lesions. ${ }^{7}$ Hassall, et al. reported that $61 \%$ of 130 children with prolonged PPI use developed ECL cell hyperplasia, with a minority developing grade 2 hyperplasia. ${ }^{16}$ Gao et al and a systematic review/meta-analysis by Tran-Duy et al reported increased risk of FGP formation and PPI use, while the impact of length of PPI therapy is uncertain. ${ }^{13,17}$ Vieth et al found no clear association between more than one month of use, while Martin et al found a 4-5-fold increase after one year of continuous use. $^{18,19}$ 
Also related to ECL cell hyperplasia is the risk of gastric carcinoid tumors and well-differentiated gastric neuroendocrine tumors (gNETs). Tranh et al. successfully reported on 66 patients with gastric tumor without chronic atrophic gastritis, MEN 1, or ZollingerElison syndrome, which is divided into 38 patients with at least 1 year of PPI use and 28 patients with no to less than one year of PPI use. The background gastric mucosa in patients with at least one year of PPI use is more pronounced in changes related to PPI use (dilation of oxyntic glands and parietal glands with apocrinelike swelling and cytoplasmic snouting) than controls. Significantly related as counterpoint to our study is the fact that 11 of 38 patients with gastric cancer and more than 1 year of PPI use had various levels of ECL cell hyperplasia. All patients have linear hyperplasia, while 5 patients have focal nodular hyperplasia. Notably, no dysplasia was noted. In general, this hitherto unidentified subtype of tumor seem to be significantly more surviveable on follow-up (no patients of the case group died vs. 3 of 28 patients in the control group; KaplanMeyer overall survival $p=0.035$ ). However, it has so far has been left undescribeddue to lack of research on the long-term ( $>10$ years) side effect of PPIs. ${ }^{20}$ Several epidemiological studies also reported a 2-to-3 fold increase of risk of developing gastric cancer in patients with long-term PPI use without $H$. pylori in Hong Kong, Sweden, Taiwan, and Japan. ${ }^{21-24}$ Even so, the study from Cheung, et al. is based on prescription history, and thus might not account for patients with second or third-line therapy for $H$. pylori (i.e., the patients included might not have totally been eliminated of $H$. pylori). ${ }^{25}$

Concerningly, this finding coincides with the stopping of trends of decrease in gastric cancer, as well as the aforementioned discovery of ECL cell hyperplasia and benign tumors. Thus, more malignant gastric tumor due to PPIs are possible to occur in the future, and might need to be countered with new drugs such as the gastrin inhibitor netazepide, or other chemopreventive drugs such as aspirin. ${ }^{24,26}$ In the more superficial gastric hyperplastic polyps in the Chinese population, several characteristics leading to increased carcinogenesis risk include strawberry-like appearance with polyp erosions, anemia, as well as positive serum parietal cell antigen, hypergastrinemia, and female gender. Autoimmune metaplastic atrophic gastritis (AMAG) is also a main risk factor of neoplastic transformation in these type of polyps. ${ }^{27}$

The results of this study seems to disprove associations between duration of PPI use (i.e., hypergastrinemia) and ECL cell hyperplasia. However, the other agents physiologically involved in ECL hyperplasia are less likely, including vagal stimulation through paracrine activity of the pituitary adenylate cyclase-activating peptide (PACAP) or downregulation of somatostatin. ${ }^{28}$ Therefore, either an unknown mechanism impacting ECL cell hyperplasia or other mechanisms causing parietal cell hyperfunction (such as, similarly to mechanisms causing ECL cell hyperplasia, vagal stimulation and increased gastrin secretion, but also increased levels of histamine from non-ECL cell sources, ghrellin, apelin, motilin, and glucocorticoids) might be in play in initiating the pathogenesis of FGPs. ${ }^{29}$ Different genotypic variants or lack of study population, as well as the lack of longterm timeframe ( $>10$ years)may more likely account for this difference in conclusion from other studies, given that the theoretical basis of hypergastrinemia leading to ECL cell hyperplasia is very sound. ${ }^{30}$

This study is the first study surveying ECL cell hyperplasia in cases of FGP in Indonesia. However, the number of cases are limited in this study, and so a bigger sample pool drawn over longer periods of time can be useful. Further clinical parameters to assess might include clinical acid reflux assessments, serum gastrin and chromogranin $\mathrm{A}$, and gastric $\mathrm{pH}$ measurements, thus warranting collaboration with other specialties and departments. Control populations were also not used, when comparison between case and control population might have led into useful insights. More studies are warranted on this topic.

\section{CONCLUSION}

In the population diagnosed with FGP in 20162017, there are no statistically significant difference between ECL cell hyperplasia in long-term and shortterm PPI users.

\section{Ethics}

This research has been assessed by the Medical Research Ethics Committee, Faculty of Medicine, Universitas Indonesia - Cipto Mangunkusumo Hospital, and declared the protocols ethically sound in the letter No. KET-4/UN2.F1/ETIK/PPM.00.02/2021

\section{Informed Consent}

As Cipto Mangunkusumo Hospital is a teaching hospital, patients have consented to a general consent for use of their medical data in the fields of education and research. 


\section{REFERENCES}

1. Ölmez Ș, Sayar S, Saritas B, Savas AY, Avclogu U, Tenlik I, et al. Analysis of patients with gastric polyps. North Clin Istanbul 2018;5:41-6.

2. Khalaf M, Brock AS, Castell D. Sporadic fundic gland polyps and gastric acid suppression level. Am J Med Sci 2017;354:561-4.

3. Islam RS, Patel NC, Lam-Himlin D, Nguyen CC. Gastric polyps: A review of clinical, endoscopic, and histopathologic features and management decisions. Gastroenterol Hepatol 2013;9:640-51.

4. Jalving M, Koornstra JJ, Wesseling J, Boezen HM, De Jong S, Kleibeuker JH. Increased risk of fundic gland polyps during long-term proton pump inhibitor therapy. Aliment Pharmacol Ther 2006;24:1341-8.

5. Fiocca R, Mastracci L, Attwood SE, Ell C, Galmiche JP, Hatlebakk J, et al. Gastric exocrine and endocrine cell morphology under prolonged acid inhibition therapy: Results of a 5-year follow-up in the LOTUS trial. Aliment Pharmacol Ther 2012;36:959-71.

6. Jianu CS, Fossmark R, Viset T, Qvigstad G, Sørdal O, Mårvik $\mathrm{R}$, et al. Gastric carcinoids after long-term use of a proton pump inhibitor. Aliment Pharmacol Ther 2012;36:644-9.

7. Tatsuguchi A, Hoshino S, Kawami N, Gudis K, Nomura T, Shimizu A, et al. Influence of hypergastrinemia secondary to long-term proton pump inhibitor treatment on ECL cell tumorigenesis in human gastric mucosa. Pathol Res Pract 2020;216:153113.

8. Malfertheiner P, Kandulski A, Venerito M. Proton-pump inhibitors: understanding the complications and risks. Nat Rev Gastroenterol Hepatol 2017;14:697-710.

9. Solcia E, Bordi C, Creutzfeldt W, Dayal Y, Dayan AD, Falkmer $\mathrm{S}$, et al. Histopathological classification of nonantral gastric endocrine growths in man. Digestion 1988;41:185-200.

10. Genevay M, Lauwers GY. Polyps and Tumour-Like Lesions of the Stomach. In: Morson and Dawson's Gastrointestinal Pathology [serial online] [cited 2017 December 01]. $5^{\text {th }}$ ed. Oxford, UK: Wiley-Blackwell; 2012. p. 162-79. Available from: http://doi.wiley.com/10.1002/9781118399668.ch12

11. Vos S, van der Post RS, Brosens LAA. Gastric Epithelial Polyps: When to Ponder, When to Panic. Surg Pathol Clin 2020;13:431-52.

12. McCarthy DM. Proton pump inhibitor use, hypergastrinemia, and gastric carcinoids-what is the relationship? Int J Mol Sci 2020;21:1-12.

13. Gao W, Huang Y, Lu S, Li C. The clinicopathological characteristics of gastric polyps and the relationship between fundic gland polyps, Helicobacter pylori infection, and proton pump inhibitors. Ann Palliat Med 2021;10:2108-14.

14. Hage E, Hendel L, Gustafsen J, Hendel J. Histopathology of the gastric oxyntic mucosa in two different patient groups during long-term treatment with omeprazole. Eur J Gastroenterol Hepatol 2003;15:781-9.

15. Camilo SMP, Almeida ÉC de S, Sousa JB, Camilo LP, Etchebehere RM. Chronic use of proton pump inhibitors and the quantity of G, D, and ECL cells in the stomach. Arq Bras Cir Dig 2020;33:1-5.

16. Hassall E, Owen D, Kerr W, Sturby T, Richardson P, El-Serag H. Gastric histology in children treated with proton pump inhibitors long term, with emphasis on enterochromaffin celllike hyperplasia. Aliment Pharmacol Ther 2011;33:829-36.

17. Tran-Duy A, Spaetgens B, Hoes AW, de Wit NJ, Stehouwer
CDA. Use of proton pump inhibitors and risks of fundic gland polyps and gastric cancer: systematic review and metaanalysis. Clin Gastroenterol Hepatol 2016;14:1706-19.

18. Vieth M, Stolte M. Fundic gland polyps are not induced by proton pump inhibitor therapy. Am J Clin Pathol 2001;116:716-20.

19. Martin FC, Chenevix-Trench G, Yeomans ND. Systematic review with meta-analysis: fundic gland polyps and proton pump inhibitors. Aliment Pharmacol Ther 2016;44:915-25.

20. Trinh VQH, Shi C, Ma C. Gastric neuroendocrine tumours from long-term proton pump inhibitor users are indolent tumours with good prognosis. Histopathology 2020;77:86576.

21. Cheung KS, Chan EW, Wong AYS, Chen L, Wong ICK, Leung WK. Long-term proton pump inhibitors and risk of gastric cancer development after treatment for Helicobacter pylori: A population-based study. Gut 2018;67:28-35.

22. Brusselaers N, Wahlin K, Engstrand L, Lagergren J. Maintenance therapy with proton pump inhibitors and risk of gastric cancer: A nationwide population-based cohort study in Sweden. BMJ Open 2017;7(10).

23. Niikura R, Hayakawa Y, Hirata Y, Yamada A, Fujishiro M, Koike $\mathrm{K}$. Long-term proton pump inhibitor use is a risk factor of gastric cancer after treatment for Helicobacter pylori: a retrospective cohort analysis. Gut 2018;67:1908-10.

24. Cheung KS, Leung WK. Long-term use of proton-pump inhibitors and risk of gastric cancer: a review of the current evidence. Therap Adv Gastroenterol 2019;12:1-11.

25. Suzuki H, Matsuzaki J. Helicobacter pylori eradication failure may have confounded the recent large-scale health database study that showed proton pump inhibitors increase gastric cancer risk. Gut 2018;67:2071-2.

26. Waldum HL, Hauso Ø, Brenna E, Qvigstad G, Fossmark R. Does long-term profound inhibition of gastric acid secretion increase the risk of ECL cell-derived tumors in man? Scand J Gastroenterol 2016;51:767-73.

27. Hu H, Zhang Q, Chen G, Pritchard DM, Zhang S. Risk factors and clinical correlates of neoplastic transformation in gastric hyperplastic polyps in Chinese patients. Sci Rep 2020;10:1-8.

28. Waldum HL, Sørdal ØF, Mjønes PG. The enterochromaffinlike [ECL] cell—central in gastric physiology and pathology. Int J Mol Sci 2019;20:2444.

29. Engevik AC, Kaji I, Goldenring JR. The physiology of the gastric parietal cell. Physiol Rev 2020;100:573-602.

30. Fossmark R, Martinsen TC, Waldum HL. Adverse effects of proton pump inhibitors-evidence and plausibility. Int J Mol Sci 2019;20:5203. 